Cinémas

Revue d'études cinématographiques

Journal of Film Studies

\title{
St. Paul : The Unmade Movie
}

\section{Silvestra Mariniello}

Volume 9, numéro 2-3, printemps 1999

Les Scénarios fictifs

URI : https://id.erudit.org/iderudit/024787ar

DOI : https://doi.org/10.7202/024787ar

Aller au sommaire du numéro

\section{Éditeur(s)}

Cinémas

\section{ISSN}

1181-6945 (imprimé)

1705-6500 (numérique)

Découvrir la revue

Citer cet article

Mariniello, S. (1999). St. Paul : The Unmade Movie. Cinémas, 9(2-3), 67-84. https://doi.org/10.7202/024787ar

\section{Résumé de l'article}

Cet article discute la notion de scénario élaborée par le metteur en scène Pier Paolo Pasolini dans son essai « Le scénario comme structure tendant à être une autre structure » à partir du projet pour le film Saint Paul. Ce film, qui devait transposer l'histoire de l'apôtre à notre époque, en la situant à New York (Rome), Paris (Jérusalem), la Rome actuelle (Athènes) et Londres (Alexandrie), n'a jamais été réalisé. Il s'agit d'un texte qui condense toute la poétique cinématographique pasolinienne et qui habite de façon critique et consciente ce lieu intermédiaire entre l'écriture et le cinéma propre à tout scénario. La tâche de cet article est de montrer le mouvement, le jeu d'allusions et de renvois qui constituent la nature même du scénario cinématographique.
Ce document est protégé par la loi sur le droit d'auteur. L'utilisation des services d'Érudit (y compris la reproduction) est assujettie à sa politique d'utilisation que vous pouvez consulter en ligne.

https://apropos.erudit.org/fr/usagers/politique-dutilisation/ 


\title{
St. Paul: The Unmade Movie
}

\section{Silvestra Mariniello}

\begin{abstract}
RÉSUMÉ
Cet article discute la notion de scénario élaborée par le metteur en scène Pier Paolo Pasolini dans son essai "Le scénario comme structure tendant à être une autre structure" à partir du projet pour le film Saint Paul. Ce film, qui devait transposer l'histoire de l'apôtre à notre époque, en la situant à New York (Rome), Paris (Jérusalem), la Rome actuelle (Athènes) et Londres (Alexandrie), n'a jamais été réalisé. Il s'agit d'un texte qui condense toure la poétique cinématographique pasolinienne et qui habite de façon critique et consciente ce lieu intermédiaire entre l'écriture et le cinéma propre à tout scénario. La tâche de cet article est de montrer le mouvement, le jeu d'allusions et de renvois qui constituent la nature même du scénario cinématographique.
\end{abstract}

\section{ABSTRACT}

This essay addresses the notion of "screenplay" elaborated by the film director Pier Paolo Pasolini, in his essay "The Screenplay as a 'Structure That Wants to be Another Structure', " with reference to his Project for a Film of St. Paul. Pasolini's St. Paul, which would have transposed the story of the apostle into our own day, by situating it in New York (Rome), Paris (Jerusalem), present day Rome (Athens), and London (Alexandria), never made it to film. The project, however, gives the whole of Pasolini's cinematographic poetic in condensed form; it is a text which inhabits, in a critical and self-conscious way, the space between writing and film which is proper to the screenplay. The aim of this essay is to show the movement, the play of allusions and references, that form the very basis of the cinematographic screenplay. 
Eh già, per Noi tutto questo tempo è stata una parentesi, / chiusa dal Nostro arrivo. Furono aboliti / questi eterni due millenni. Il punto in cui Paolo / era lì e il punto in cui Noi arrivammo furono contigui / Eh già, la forma d'uovo del tempo ci congiunge tutti.

Pier Paolo Pasolini, "The Screenplay as a "Structure That

Wants to be Another Structure" "

\section{The Screenplay: A Nonevolutionary Process}

In 1965, Pasolini wrote the important essay entitled "The Screenplay as a "Structure That Wants to Be Another Structure. " Its main point is that the screenplay is an autonomous work whose "substantive" character is " $[\ldots]$ the allusion to a potential cinematographic work." (1988, p. 188) The truly innovative elements in Pasolini's discourse are, firstly, the description of such "allusion" as a dynamic, a nonevolutionary process - "In the details is only a void, a dynamic that it is not made concrete; it is like a fragment of strength without a destination" (p. 188, my emphasis) - and secondly, the emphasis on the coexistence of two different linguistic systems (langues) in the screenplay-text (sceno-testo). Writing a screenplay does not simply entail adopting a different (literary) technique, but also functioning in a different language.

Any linguistic sign is a combination of three moments: the "phoneme" (the oral moment of the sign), the "grapheme" (the written moment of the sign) and the "kineme" (the visual moment of the sign). "Through an incalculable series of conditioned reflexes of our mysterious cybernetics, we always have simultaneously present these different aspects of the linguistic 'sign' which is therefore one and three." (p. 189) In the word of the screenplay-text, the visual moment is more important than the other two. But what is this visual moment? Pasolini defines "kinemes" in terms of "primordial images" - "visual monads" with only a virtual existence. "The image is born of 


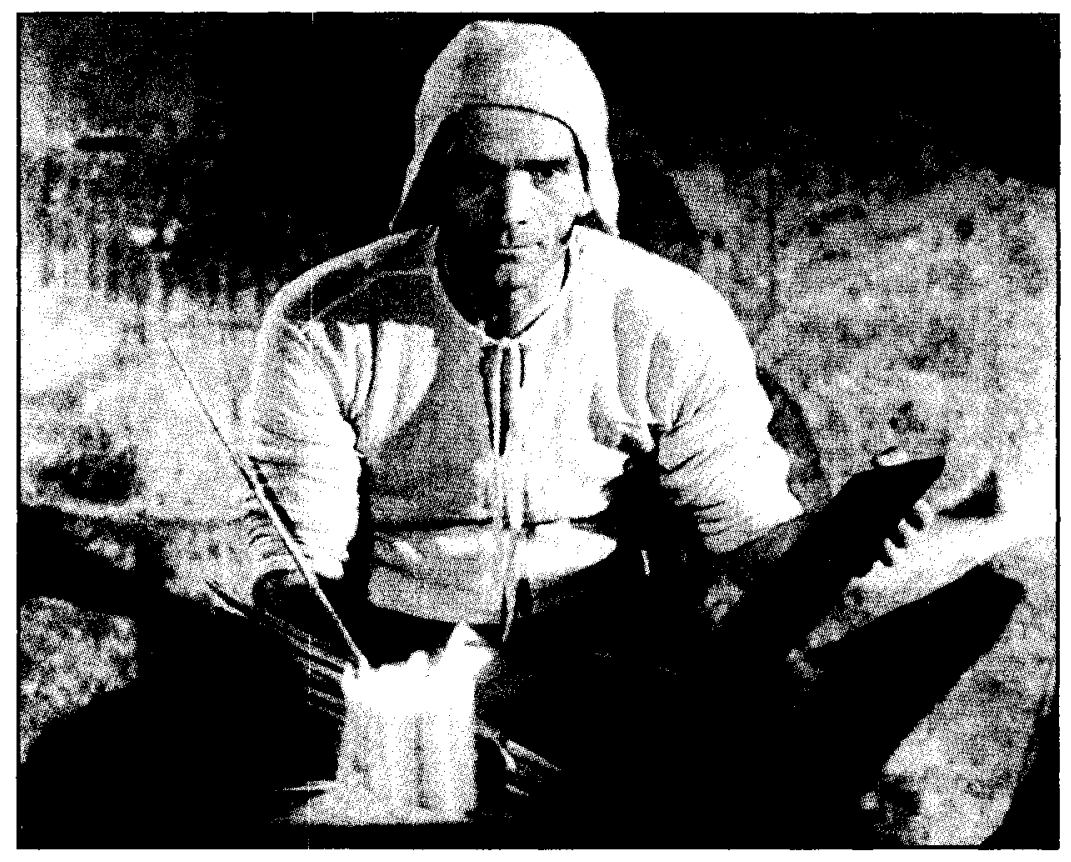

\section{Pasolini in Les Confes de Canferbury (1971)}

the coordination of the kinemes." (p. 190) Here we encounter an initial problem: the tendency to discuss the coordination of kinemes in terms of syntax, by analogy with the combination of signs in written and spoken language. "Any study of film, Pasolini writes, is vitiated by this genesis in a linguistic model." (p. 190) To understand the quality and potential of the visual monads inhabiting the screenplay, it is necessary to free film from this linguistic model. The question then becomes: "If cinema is another language, cannot this unknown language be predicated on laws that have nothing to do with the linguistic laws to which we have become accustomed?" (p. 191) The hybrid nature of the screenplay-text, and thus its subversiveness, only becomes apparent when we come to accept that any parallel between cinematographic image and linguistic sign is arbitrary, that the most we can affirm is that cinema is another language.

Let's go back for a moment to the beginning of Pasolini's essay, where he states that the "substantive" character of the 
screenplay-text is its allusion to a potential cinematographic work. This allusion implies someone, a reader capable of responding to and participating in the game the text sets in play. In fact, the screenplay-text is defined by " [...] a special and canonical request for collaboration from the reader to see the kineme in the grapheme, above all, and thus to think in images, reconstructing in his own head the film to which the screenplay alludes as a potential work." (p. 192)

What is of paramount importance to Pasolini in the latter half of the essay is that the kineme, which the reader comes to see, belongs to another linguistic system. "The sign of the screenplay therefore not only expresses ' a will of the form to become another' above and beyond the form; that is, it captures 'the form in movement," but "[...] what is most important to observe is that the word of the screenplay is thus, contemporaneously, the sign of two different structures, inasmuch as the meaning that it denotes is double: and it belongs to two languages characterized by different structures." (p. 192-193) Situated as it is between literature and film, the screenplay-text occupies a "void", an interval which compels the reader to inhabit that same uncomfortable place between two languages. With what consequences? What is at stake in such a theory, besides the freedom of an author who chooses to abandon the immobility of the structure for the openness of the process? The reference to Levy-Strauss and his notion of structure is not gratuitous. Anthropology had analyzed and catalogued life and historical dynamics. Though taking a necessary step beyond the Western, linear, evolutionary conception of history, structuralism nonetheless ended up trapping the historical subject within a cagestructure. With Pasolini, however, the screenplay comes to perform a special role, for the simple reason that it

[...] is a diachronic structure... an actual process. But a specific process in that it is not a question of an evolution, of a passage from a phase $A$ to a phase $B$, but of a pure and simple dynamism, of a tension which moves, without departing or arriving, from a stylistic structure - that of narrative - to another stylistic structure that of cinema - and more deeply from one linguistic 
system to another [...]. The screenplay-text's structure, which is dynamic but without functionality, and outside the laws of evolution, lends itself perfectly as object for a clash between the by now traditional concept of structure and the critical concept of process. (p. 193)

What is most relevant here is the emphasis on the dynamic nature of the text, on the tension between the two languages, on the process per se. The point of departure and the ultimate accomplishment do not constitute the essence of the screenplay, nor can the two "structures" (the written text and the potential film) be separated or reduced to simple "objects." The clash between the "traditional concept of structure" and the "critical concept of process" has, as we will see, important political implications.

\section{The Project for a Film of St. Paul}

In a note to the 1977 edition of Pasolini's San Paolo (Pasolini, 1977), the editor provides some important information regarding the history of this project, one that was never made into a film. Pasolini wrote a first version of his St. Paul in 1968: the Draft of a Screenplay for a Film of St. Paul (In the Form of Notes to a Producer). The Project for a Film of St. Paul, which precedes the Draft in the Einaudi edition, was written over the same period. For a variety of reasons, Pasolini could not make the film at that particular time. Later, in 1974, a renewed attempt was made with different producers. Eventually, however, the subject was deemed too "risky" and found to require too much money. Pasolini reviewed the manuscript, but a new, definitive version was never completed. Following Pasolini's death, Einaudi published this "unmade movie," making every effort to be as faithful as possible to the author's revisions.

In his Project for a Film of St. Paul, Pasolini explains how he would go about making the movie and what its political and poetic implications would be. The underlying "poetic idea" of the whole project is the transposition of the preaching of St. Paul, of Paul's life itself, into our time. While Paul's words would be taken literally from The Acts of the Apostles, his clothes, 
the objects surrounding him, the cities he crosses, the places he visits, and the social and political conflicts encountered, would be contemporary.

\begin{abstract}
Why would I transpose the worldly events of his life into our time? It is very simple: to give cinematographically, in the most direct and violent way, the impression and the certitude of his actuality. In sum, to tell the viewer explicitly, and without even forcing him to think, that "St. Paul is here, today, among us," and almost physically and materially so. That it is our society he is addressing, our society he cries over and loves, threatens and forgives, attacks and gently embraces. $(1977$, p. 5)
\end{abstract}

A series of transpositions would then take place following the "temporal violence" done to St. Paul's life (p. 5). Again, Pasolini chooses analogy as a way in which to write history with film.

According to him, film cannot represent the past. People and places, in fact, bear the indelible marks of the present. While doing the sopralluoghi in Palestine, prior to shooting his Gospel According to Matthew (1964), he reached the conclusion that the most effective way for film to write history was by identifying and drawing analogies between past and present. Analogy, understood in Pasolini's sense, is both identity and difference, at one and the same time. Past and present enter upon a strange relationship that casts each in a new light.

"The first and foremost of these transpositions consists in substituting the conformity of St. Paul's times [...] with a contemporary conformity." (p. 5-6). Conformity, which, according to Pasolini, bears the greatest responsibility to the horrors of contemporary society, is ever a target for his critique (cf. Mamma Roma, 1962; La Rabbia, 1963; Teorema, 1968). By replacing the conformity of Jews and Gentiles with that of today's bourgeois (religious or not), the text historicizes the past, and biblical history, introducing elements of a materialist analysis: of institutional religion's and liberalism's relation to power. But it also translates the consequences of that conformity - the crucifixion of Jesus - into contemporary terms, since it is a conformity capable of crimes at least as horrible. The world in 


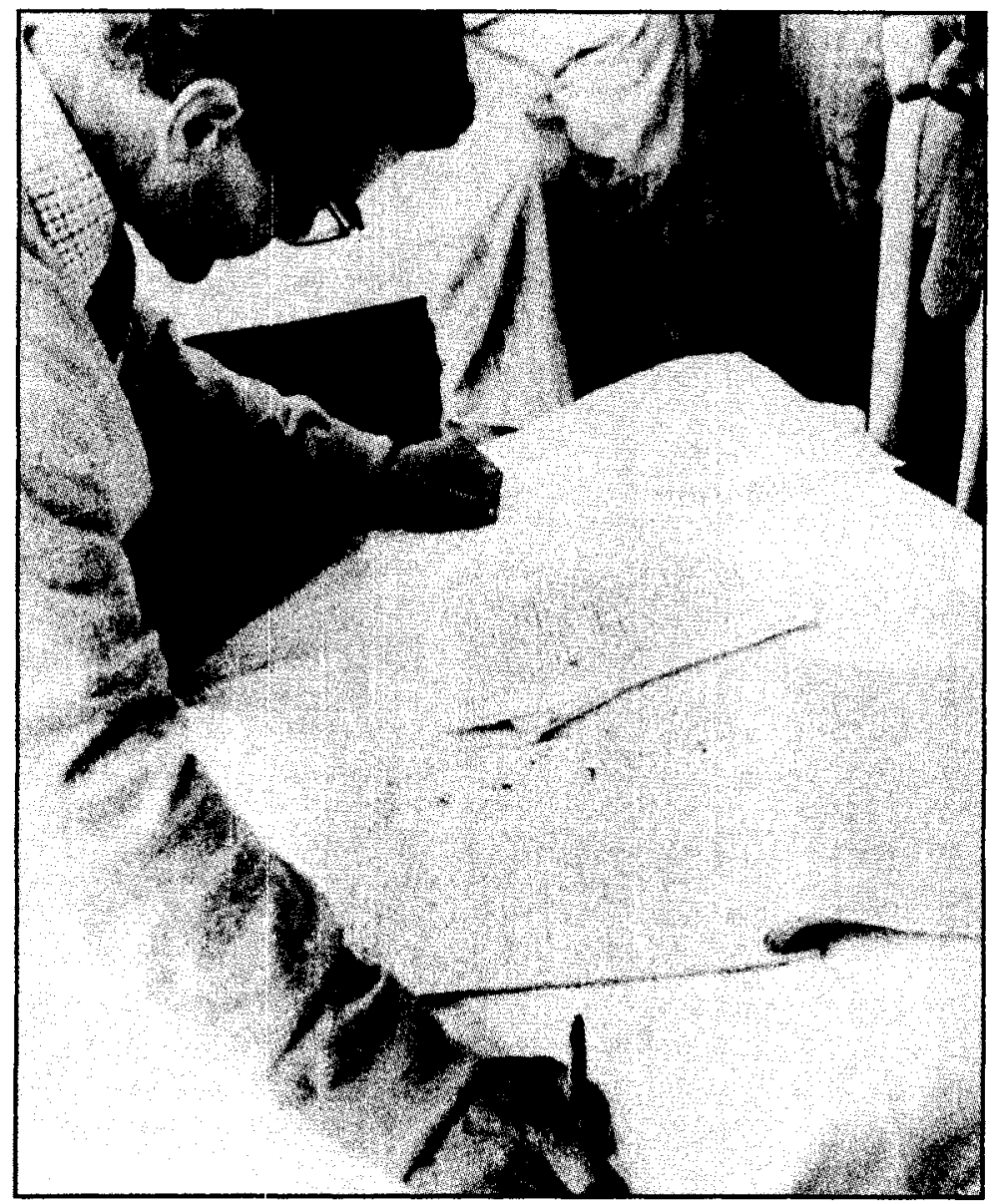

Pasolini on the set of Teorema (1968)

which Pasolini's Paul moves is that of the sixties, in particular that of ' 66 or ' 67 . The bari-center of the political and economic power is no longer Rome and the Mediterranean; different geopolitical realities come to replace the historical ones in the play of transpositions of which Pasolini's text consists. New York replaces Rome, and Paris Jerusalem, as the " $[\ldots]$ cultural, ideological, the civilized, in its own way, religious center." (p. 6) Today's Rome corresponds to ancient Athens, while Antioc is replaced by London or Geneva. In the 1974 version of the screenplay, changes were made with respect to the "geography" 
of the story. The interesting feature I wish to point out is that the changes " [...] were not dictated by pressures of a production order: there was in Pasolini an exigency of actuality that led him, after six years, to different historical and geographical choices" (the editor, Pasolini 1977, p. 170).

The narrative structure Pasolini intended to lend the film would have been that of an "episodic tragedy" (1977, p. 7), drawing on some of the salient events of Paul's life, beginning with the martyrdom of Stephen, as told in "The Acts of the Apostles." Above each episode would be marked the "real" date (such as 45 or $49 \mathrm{AD}$ ); and " [...] in the film, before the credits, the map of St. Paul's real itinerary would replace the one with the transposed itinerary." (p. 7)

To understand the meaning of the operation that the "unmade film" undertakes, it is necessary for me to give a brief account of the events narrated in the screenplay. The scene opens in Nazi occupied Paris (Jerusalem). In lieu of Romans the reader / viewer is confronted with members of the SS; and French "conservatives" and collaborators stand in for Pharisees. The Apostles, dressed like bourgeois intellectuals and workers of the late thirties, are partisans of the Resistance to the regime. Stephen, a young partisan, is arrested and subsequently shot by the SS. His speech is as it is found in the Bible, while Paul, likewise, appears among Stephen's persecutors. In the following episode, Paul is sent to Barcelona (Damascus) to pursue his operations against the Resistance. On his way by car to Barcelona, however, he is blinded and called by God to join the Resistance. Ananias, a French rebel exiled in Spain, becomes his guide. Wanted by his former companions, and not yet fully accepted by his new ones, Paul sets out into the desert. To render the desert experience, Pasolini evokes the solitude of contemporary consumer society.

No desert will ever be more deserted than a house, a square, a street where people live one thousand nine hundred and seventy years after Christ. Here is solitude. Side by side with your neighbor, dressed by the same department stores, clients of the same shops, readers of the same newspapers, viewers of the same TV shows, it is silence. 
There is no other metaphor for the desert than everyday life. It is unrepresentable, because it is the shadow of life: and its silences are internal. It is one blessing of peace. But peace is not always better than war. In a peace dominated by power, one can protest by refusing to exist $[\ldots]$. (p. 35-36)

Paul returns to Paris, and from there goes to Tarsus, his home town. Tarsus is designated in the screenplay as simply a "European city". There, Barnabus will meet Paul, and together they will head to Geneva (Antioc) to preach. Parallel to the story of Paul's travels and his preaching and miracles, which follows the narrative of the biblical text, the screenplay tells the story of the writing of The Acts. Luke, possessed by Satan, writes the story we are actually reading, and his writing, as we will see, will form an integral part of the foundation of the Church as a power structure.

In Geneva, Paul takes leave of Barnabus, and wanders through various places before finally arriving in Germany (Macedonia), where he is arrested and put on trial. Once liberated, Paul travels to Rome (Athens), where he speaks before a class of cynical intellectuals, indifferent to his word. The Roman episode closes with an exegesis of Paul, throughout which different experts interpret the concept of redemption according to psychoanalytic categories. The traveling and preaching bring him next to Genoa (Corinth), where the text of Paul's speeches faithfully reproduces the Epistles to the Corinthians, and from there to Naples (Ephesus).

Back once again in Paris, Paul becomes increasingly isolated within the institution of the Church, where his activity begins to threaten the political establishment. Arrested just as he is about to be lynched by a group of fascists, Paul is imprisoned and taken from Paris to Vichy in order to avoid being murdered at the hands of enemies. In the screenplay, Vichy is symbolic of the continuity between fascism and democracy. "At this point there is a leap [...] from the German occupation to the American. Formally, they are one and the same. Power has the same face, etc. So the new authority is escorted by American policemen rather than the SS." (p. 127) 
Since Paul insists on being judged by Caesar, he is sent to Rome. The conclusion to the film is supposed to take place in New York (Rome), where the lines Paul delivers are basically those from his Epistle to the Hebrews and Epistle to the Romans. Misunderstood, isolated and marginal, but still "disturbing," Paul is killed in his hotel - the very one in which Martin Luther King was killed.

The novelty and poetry of the film were to be seen, as Pasolini says in the project, in the gap between the two temporalities, in the dramatic conflict between the time of the present and the sacred.

The questions the converted will ask Saint Paul will be those from modern people, specific, detailed, problematic, political, uttered in a language typical of our times; St. Paul's answers, instead, will be what they are: namely, merely religious, and furthermore uttered in St. Paul's typical language, universal and eternal, but outdated (strictly speaking).

Through this process, the film will reveal its profound subject: which is the contrapositioning of the present (attualita) and the sacred (santita) : the world of history, tending in its excessive, urgent presence, to escape into mystery, abstraction, and mere questioning, and the world of the divine, that, on the contrary, in its religious abstractness, comes down among people, becomes concrete and operating. (p. 7)

\section{The Fictitious Screenplay: The Only Solution?}

We are in the presence of a twofold experience, we could almost talk of a mirror effect or, rather, a rebound effect. On one side, the screenplay: a process, a dynamic moment, something in between two recognizable "realities" - literature and film. On the other, the analogy: again a process, a dynamic moment, something in between two recognizable realities: the sacred past and the present. One thing cannot turn into the other, the past does not become the symbol of the present; rather, it is the dynamic between them that counts. Just as the screenplay-text only makes sense in the play of cross-references 
between the written and the (audio) visual signes evoked in the mind of the reader, the analogy can only make sense in the play of cross-references between the sacred past and contemporary history.

My hypothesis is that the fictitious screenplay, the unmade movie, by an almost internal necessity cannot be turned into a film. In other words, the shock that Paul's words provoke, uttered in the present, takes place precisely in the interstice between the two structures (the literary text and the film), and it is more effective because of the site of its happening. Only the fictitious screenplay seems to allow the extraordinary potential of St. Pauls poetic idea to fulfill itself.

The whole text proves very rich and challenging for my hypothesis. We could, for instance, consider the first episode set in Nazi occupied Paris; in particular, we could briefly analyze the fragment of Stephen's trial. The young partisan (apostle) is brought before the court for a summary trial: "On the defendant's bench is Stephen, handcuffed [...]. The witnesses follow one after another" (1977, p. 19) to testify against him. These few lines from the screenplay introduce the reader to a familiar situation: the courtroom, the defendant, the witnesses. The cinematographic and literary "encyclopedia" required by the read$e r$, in order to understand the situation, is one found in his or her common heritage. The words to describe the sequence of events, though, as well as the discourses pronounced by different characters, are not in the least what we would expect. The whole trial is told through the words of the Bible.

And all that sat in the council, looking stedfastly on him, saw his face as it had been the face of an angel [...] Ye sitffnecked and uncircumcised in heart and ears, ye do always resist the Holy Ghost: as your fathers did, so do ye [...]. Which of the prophets have not your fathers persecuted? And they have slain them which shewed before of the coming of the Just One; of whom ye have been now the betrayers and murderers [...]. When they heard these things, they were cut to the heart, and they gnashed on him with their teeth. (Acre, 6,7:14-54) 
The admixture of biblical words and historical reality - the episode is introduced by documentary footage from the actual Nazi occupation of Paris; and after Stephen's execution, further documentary footage follows from the most dramatic scenes of that time - is shocking for the reader. All the more so because it is not constructed as an allegory, for instance, which would create a new synthesis. It is the contiguity, the bringing together of two "incompatible" discourses (religion and history exclude each other within Western rationalism) that proves shocking and scandalous. Such contiguity is only possible in poetry, or in a screenplay, where the dynamic between two structures (the literary and the cinematographic) does not provide connections, but leaves them to the reader / viewer to establish.

The square where Stephen is shot is presented in the screenplay-text as familiar to those who lived through the war and the experience of those trials: "It is one of those sites, so familiar to our terrified memory and to our dreams, where executions took place between ' 38 and '45." (1977, p. 20) The text seeks the complicity of the viewer who shares these historical and personal memories, while at the same time disorienting him / her with the biblical fragments that impose a reconsideration of history and historical discourse.

Written words, images evoked, and the imaginary of the reader, who is called to put together different temporalities, different genres, different realities - in particular history, recent events, and the Bible - participate in this rewriting of history throughout the whole text.

I will concentrate, for this last part of my study, on passages selected from the New York episode, which still seems the most significant within my chosen perspective. In other words, the one that best helps to understand the theoretical and political implications of the complex process that unfolds in this screenplay.

New York $63 \mathrm{AD}$. This chapter is one of the most intense in the whole text. The New York Court House, the yard in front of the humble hotel where Paul is staying on the West Side, and the big ballroom in the Village are the sites for the action.

What is actual are the courtroom, the American policemen, the people waiting outside the Court House: Blacks, white sub- 
proletarians, a few intellectuals, and some "multicolored and desperate" youths. So too are the ballroom in the Village, the crowd, the stage, the microphone, St. Paul before an audience, like Ginsberg. Actuality is identified by the scandal and indignation elicited by Paul's words among members of the audience. Actuality is seen in the comments of some intellectuals, their way of reasoning especially. Actuality receives those biblical words :

For none of us liveth to himself, and no man dieth to himself. For whether we live, we live unto the Lord; and whether we die we die unto the Lord: whether we live therefore, or die, we are the Lord's. [...] But why dost thou judge thy brother? or why dost thou set at nought thy brother? for we shall all stand before the judgment seat of Christ [...]. (Romans, 14:7-10)

What happens between actuality and the sacred past? What transpires in the encounter of the two? The contemporary West Side crowd is "altered" in its contact with biblical language. A compassionate understanding arises between the description of the people and the utterance of the words. The description is not an objective, realistic one. The hippies, "[...] dirty and provocative enough to infuriate the most liberal of bourgeois" (p. 138) are looked at through nonbourgeois eyes; the crowd, gathering respectfully around St. Paul, eager to know and understand, " $[\ldots]$ according to the habits almost mystically democratic of the Village" (p. 138) is the object of a sympathetic look, of a poetical discourse.

What I am trying to argue is that this happens because the description of the crowd is followed by the biblical words, and because the reader / viewer is with St. Paul in a time which is neither that of the past nor the present. A time that strips human reality of its empirical historicity; a time producing an alternate historicity: materialist and poetical, non institutional. The reader / viewer is drawn by the screenplay-text to see and hear the shocking effect of the coexistence of the two dimensions. For instance, the screenplay-text presents the crowd. I choose this verb - present - for its meaning of introducing someone who is going to act, someone whose features take 
shape with his or her action. "Describing," on the other hand, is a verb rather that introduces the object (character) of a discourse (novelistic or other). The abundance of deictics evokes for the reader something to look at, as happens in oral performances. Passing from this "presentation" to the words of the Epistles, uttered directly without any premise that could help the reader to switch from one reality to the other, is done abruptly: "He opens his mouth and begins to talk." The limit between past and present collapses, disfiguring each temporality in the process.

Paul speaks. His words, from his Epistle to the Romans, are dangerously rigid and authoritarian. The text offers the reader the biblical words and the reaction of the crowd.

Let every soul be subject unto the higher power. For there is no power but of God: the powers that be are ordained of God. Whosoever therefore resisteth the power, resisteth the ordinance of God: and they that resist shall receive to themsevlves damnation. For rulers are not a terror to good works, but to the evil. Wilt thou then not be afraid of the power? do that which is good, and then shalt have praise of the same [...]. Werefore ye must needs be subject, not only for wrath, but also for conscience sake [...]. Render therefore to all their dues: tribute to whom tribute is due; custom to whom custom; fear to whom fear; honour to whom honour. (Romans, 13:1-7)

Again, something happens in this dual in-between space which the St. Paul screenplay inhabits. The crowd from the present, reacts to the words without understanding their origin or source, incorporating them within its world view, within its empirical reality.

With insight and lucidity, the text shows the tragic absurdity of History. People react the way they must; they say the right things, yet they are wrong, they miss something. The historical Left - as it appears in the text - is born in this in-between, out of the lack of comprehension of religion, in rigid opposition to a discourse it fails to understand, out of a will to transparency. Those the screenplay-text presents come to represent the Left 
through their reaction to the sacred past, to the words of the Bible. Moreover, when confronted with people's reactions, biblical words become institutional doctrine and the symbol of Church power. Let's consider some of the arguments.

What can you expect of this man ? He is legalistic to
the backbone even in his sermons. The archetype of
the power idea coincides with the archetypal idea he
has of God [...]. He should give up being a leader! He
has in mind a hierarchical world [...]. He is a Church
founder : he is obsessed with instituting. But every
institution is anti-democratic in itself: democracy dies
where it is fixed in one place [...]. Is it possible he does
not understand that today, here, no code can exist, no
code could be accepted, not even a revolutionary lan-
guage code? [Is it possible that he does not understand
that] revolutionary language has to be invented day by
day? (1977, p. 142)

The complexity of the text increases reaching the very limits of consistency. The multiple voices of the crowd, as I was saying, are occasionally those of the historical, orthodox Left, and at other times those of a more anarchist Left, one more aware of the dangers of institutional power. Opposition to St. Paul's preaching is almost contradicted by his following words, words Pasolini inverts from their biblical order.

What shall we say then? Is the law sin? God forbid. Nay, I had not known sin, but by the law: for I had not known lust, except the law had said, Thou shalt not covet. But sin, taking occasion by the commandment, wrought in me all manner of concupiscence. For without the law sin was dead. For I was alive without the law once: but when the commandment came, sin revived, and I died. (Romans, 7: 7-9)

I am not in a position to attempt an exegesis of St. Paul, but I would like to point out the montage in the text, which seems particularly interesting. The most "legalistic" statements are followed by indirect considerations on the paradoxical nature of the law. The criticism implied by the montage of St. Paul's texts is reinforced in the next scene, where, according to Pasolini's 
1974 revision, Satan arrives at Luke's door in Jerusalem (Rome, instead of Paris, in the revised edition).

A long dialogue was supposed to ensue, in which a sarcastically smiling Luke would recount the end of the story to Satan.

The goal has been achieved. The Church has been founded [...]. Satan is not interested in Paul's Destiny: he can save himself and go to Heaven. Satan and his hired assassin laugh scornfully, they are satisfied. Luke...gets some "champagne" from a cabinet and they repeatedly drink to their Church. (1977, p. 144)

As I mentioned above, parallel to the story of Paul' life and preaching, the screenplay tells the story of the writing of the "Acts," providing yet another mirroring and, at the same time, estranging effect. The institutionalization of the Church is not to be charged against Paul's deeds, but to the writing of the "Book," which reveals the blindness of the Left who accused him of all kinds of reactionary mischief. Paul's actions, and his conflicts with his "contemporaries," remain alive, contradictory; they remain a process (" a fragment of strength without a destination") as long as a structure is not imposed on them.

The last part of the screenplay stages Paul's solitude and marginalisation, and "liberates" his words from the apparatus that has appropriated them. It brings to mind Pasolini's abjuration of his Trilogy of Life (1975). The text compels the reader to retrace, with Paul, the sites of his preaching, up until Paul is newly arrested and "shipped" to New York. This time around, nobody is there to welcome him. Taken away, he is put in a cell with common criminals, only to be liberated shortly thereafter and ultimately killed by a hired assassin. The last part of the screenplay-text shows St. Paul writing from his humble hotel room (he is now in the same hotel where Martin Luther King was shot) to Timothy, his pupil and bishop of Naples (Ephesus). The text leads the reader through a montage of shots of Naples (the very places visited by St. Paul, along with new ones of a terrible present day poverty) and a mixage of Paul's "voice off," reciting the text of the "Letters" to Timothy and Titus. 
Put them in mind to be subject to principalities and powers, to obey magistrates, to be ready to every good work, to speak evil of no man, to be no brawlers, but gentle, shewing all meekness unto all men. (Titus, 3 : 1-2)

Let as many servants as are under the yoke count their own masters worthy of all honour, that the name of God and his doctrine be not blasphemed (I Timothy, $6: 1)$

These words were supposed to be superposed over their corresponding images. The word "servants," for instance, would be associated with a shot of poor people in an impoverished, miserable neighborhood; while the word "masters" would accompany a shot of the luxurious buildings of downtown Naples, etc. The effect is not one of questioning the value of St. Paul's words. Rather, as the reader is led to see in the following scenes, it is one of questioning the interpretation the Church has given these precepts. Could they be taken literally? How have they been understood and exploited? As the screenplay-text continues to show the corruption of the Church and the conformity of its rituals, St. Paul's words become more "true," both for the present and in an absolute sense.

This know also, that in the last days perilous times shall come. For men shall be lovers of their own selves, covetous, boasters, proud, blasphemers, disobedient to parents, unthankful, unholy, without natural affection [...]. Ever learning, and never able to come to the knowledge of the truth. (II Timothy, 3: 1-7)

These words are not so different from those Pasolini wrote in regard to consumer society.

The unmade movie stages a contrast between the written words and the reality they come to inhabit, as well as the distance - physical, geographical, and ethical - between Paul and Timothy, Paul and the Church. The conclusion holds out to the reader the possibility of recognizing Paul's actuality. His words - the screenplay-text only indicates that they are the most sublime from Paul's writings, and given in no logical order - against the background of his hotel room, just prior to his 
assassination, are liberated from their institutional destiny: they are not written, nor heard, but merely suggested, as only a screenplay can do.

\section{Université de Montréal}

\section{OUVRAGES CITES}

Pasolini, P. P. “Tarso da Lontano," Bestemmia. Tutte le poesie. Milano: Garzanti, 1993, p. 1888-1889.

Pasolini, P P. "The Screenplay as a 'Structure That Wants to Be Another Structure," Heretical Empiricism. Bloomington: Indiana University Press, 1988, p. 187-196.

Pasolini, P. P. San Paolo. Torino: Einaudi, 1977.

Pasolini, P. P. “Abiura dalla Trilogia della vita," Lettere Luterane. Torino: Einaudi, 1976, p. 71-76.

The Bible, Authorized King James Version. Oxford: Oxford University Press, 1997. 